\title{
中国で広がる謎の病気
}

\section{Mysterious disease spreads in China}

\author{
農民の原因不明の死と鳥インフルエンザとは関係があるのだろうか。
}

doi:10.1038/news050725-1/25 July 2005 Declan Butler

新華社通信が7月 24 日に伝えたとこ ろによると、それまでの 1 か月間に、 中国南西部で未知の病気によって少な <とも 17 人が死亡し、41 人の感染者 が出ているという。病気の原因はまだ わかっていないが、症状はインフルエ ンザに似ており、四川省資陽市および 内江市の近郊の町で、家畜から農民へ と広がっているとみられる。

世界保健機関（WHO）西太平洋地域 事務所（フィリピン・マニラ）の広報 担当 Bob Dietz は「まだ診断はついて いない。中国による調査が行われてお り、現地での診断結果を待ちたい」と 語る。また「鳥インフルエンザやSARS (重症急性呼吸器症候群) を含むさまざ まな病気の可能性が考えられるが、率 直なところ、病気の原因を特定できな い場合のことを心配している」と話す。

今回のような動物との関連が考えら れる唐突で原因不明の死というのは珍 しく、中国は救急隊を派遣して鳥イン フルエンザとの関係を調査している。 ただし「今回、病気の発生地域があち こちに分散していたにもかかわらず、 比較的迅速に病気が把握され公表され たことは評価できる」とDietzは話す。

同氏は、この問題が 4 週間以内に検 知されたことについて「そう悪くはな い」とし、同じことが起きれば、ニュ ーヨークのような都市でも検知に 2 週 間かかってもおかしくないと付け加え る。そして、「中国は発生を公表し、わ れわれやメディアに知らせている。中 国の監視システムがうまく機能してい るということだ」と話す。

\section{疑われる希少な病気}

中国当局は疑われていた主要な病気の うち、いくつかの可能性は消えたと公 言している。地元の衛生庁高官 Zeng Huajin は、「この病気はSARS でも炭

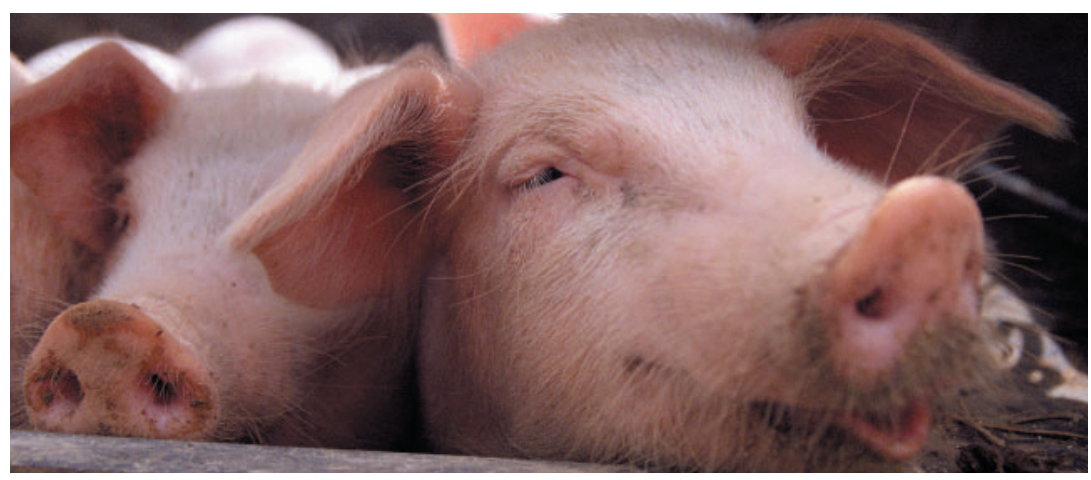

ブタは危険なウイルスを生みだす温床である。

疽病でも鳥インフルエンザでもない」 と新華社に話している。Huajin は考え られる原因について、細菌 Streptococcus suis を挙げている。この細菌はブタに感 染する主な病原体で、世界のほとんど の国で見受けられるものだ。英国健康 保護局によればヒトへの感染はまれで あり、全世界で過去 150 例足らずが報 告されているにすぎないという。

S. suisに感染した患者には重度のイン フルエンザに似た症状があらわれ、難 聴をともなう場合もある。新華社は今 回の正体不明の病気について、症状は 「高熱、疲労、嘔気および嘔吐、そのの ち皮下の挫傷をともなう昏睡状態」で、 発病したのは罹患したブタまたはヒツ ジを屠殺した農民だったと伝えている。

一方、感染症の情報を提供する ProMED メーリングリストを通じ、研 究者や医師たちは、今回の症状と、中 国南部各地の家畜で局地的に流行して いるクリミア - コンゴ出血熱 (CCHF) との類似性を指摘している。CCHF は あまり聞かれないが重症の病気で、通 常はダニが媒介し、死亡率が高い。た だしヒトからヒトには伝染しないため、 ヒトに対する危険性は限定的と考えら れる。

\section{鳥に向けられる目}

今回の病気についての診断が続けら れるなか、研究者は依然として鳥イン フルエンザの危険性を警告している。
今春、中国西部の青海湖にいた何千羽 もの渡り鳥が H5N1 型の鳥インフルエ ンザに感染した。研究者はそこから鳥 インフルエンザが広がる可能性を指摘 する。WHO の研究者は渡り鳥が感染 したウイルスについて、病原性の高い 新たな H5N1 型であることを確認して いる1。

ブタの体內では鳥インフルエンザウ イルスとヒトインフルエンザウイルス の共存が可能であるため、そこで互い のウイルスの遺伝子が交換され、感 染性のあるヒトウイルスが生まれるこ とも考えられる。国立鳥インフルエン ザ研究所（中国黒龍江省哈爾浜）の Hualan Chen 所長は「4 月の時点で検 査した中国のブタ 450 頭のうち、23\% が病原性の高くない鳥インフルエンザ ウイルス H9N2 型をもっていた」と話す。

今なお WHO の担当者は、その他の 鳥インフルエンザ発生地域への立ち入 りを中国が認めるのを待っている。中 国は、鳥インフルエンザに関する追加 情報およびウイルス検体の要求にまだ 応えていない。「それを得るのが急務 課題だ」と、WHO 北京事務所の Julie Hall 調整官は語る。

1. Chen H., et al. Nature, 436. 191-192 (2005). 